\title{
1. Law and the new normal: reimagining property
}

... to aspire to achieve a secure, pervasive unity of transnational networks of community ... involves the creation of a transnational rule of law that serves all peoples of the world. ${ }^{29}$

\section{INTRODUCTION}

In all that follows, the core argument driving our thinking is that law unhooked from its current commodified connection with exclusive private property arrangements and relationships presents a real possibility to reimagine law's processes, institutions, forms and relevance. Along with this transition, and perhaps in large part motivating its influence and directions, property as a central market variable is shifting back to more sustainable uses and locations. New law and original property ${ }^{30}$ are analytical concepts essential for understanding this tandem transformation. ${ }^{31}$

What are the frameworks essentially enabling a move to new law and original property? We say markets, their disembedding and the dispersal of power that either drives, or is a consequence of such market shift away

29 Cotterrell, R. (2006), Law, Culture and Society: Legal Ideas in the Mirror of Social Theory, Aldershot: Ashgate, p. 169.

30 New (transformed) law as it is conceived of throughout the text cannot entirely shake off law's exclusivity. Neither can our conceptualisation of original property entirely move away from commodification. The distinction as we see it is that exclusivity in terms of the relationship between new law and original property is no longer determined for the limited benefit of market economies but for a more inclusive benefit of market communities (developed in more detail in Chapters 6 and 7).

31 A more detailed exposition of new law and of original property is provided in Chapter 6. A reason for this is the necessity to appreciate how both concepts are applied in our case studies which run from Chapters 3 to 5 . As we progress through the text we employ new law and transformed law interchangeably depending on the context of the discussion. 
from the social. The analytical device of suspension ${ }^{32}$ is advanced as important for understanding the forces at work on market embedding and its dynamic continuum.

There are some powerful social and economic theories employed to appreciate markets on the move. In order to explain how communities alter their attitudes to law and property, we utilise Durkheimian thinking about the relationship between the collective conscience and law as its limit to understand the role of law as a change agent. More specifically, in focusing on the nature of social bonds at work within a dynamic collective conscience, Granovetter's writing on strong and weak ties is drawn down to explain the forces that impact on a changing collective conscience. Underneath all this it becomes necessary to unpack our two key analytical paradigms, new law and original property. In constructing the interpretation of original property, the analysis returns to Proudhonian theory regarding the nature and consequences of class-based commodification. For the purposes of revealing market dynamics wherein new law and original property are at play through influencing disembedding and power dispersal, we grow out from Polanyi's thinking about double movement and countermovement. The theoretical purpose by this stage is to potentially return property and law to the social. Finally, in advancing the notion and possibility of new law, the analysis picks up Cotterrell's communitarian theorising of law as a communal resource.

The text takes on the task, in the context of an emerging new collective conscience:

- to understand how law functions as an agent of change (resistant or reformative);

- to reveal how the formulation of a new collective consciousness challenges conventional relationships between law and property;

- to speculate on how commodification disembeds the market from the social, and chart the role for new law and original property; and

- to explore how the creation of a new dissent space within which law can operate will lead to a more orderly transition of property, commodification and market power.

32 In his recent book, (2016), How Did We Get into This Mess; Politics, Equality, Nature, London: Verso, George Monbiot refers to the 'infrastructure of persuasion' which could be seen as the devices and forces which produce suspension. 
If we were to advance a prevailing analytical purpose, it would be critically tracing the development of new law as an agent of change within a rapidly reforming collective conscience concerning property and commodification. With the intent of arguing law's potential regulatory relevance in such a change epoch, we set out to theorise new law and its evolving relationships with original property as a stronger and more sustainable process for enabling social ties and bonding within times of radical transition in market arrangements and relations.

The method we employ is as diverse as it is inclusive. Case studies provide the platform for applying the lens of social anthropology to explore the manner in which key social spaces (such as the internet), key market players (such as proprietors), key market forces (such as commodification) and key forces for change (such as power relations) participate in the evolution of alternative arrangements between law and property. Critical legal studies techniques are applied when approaching the present reactionary depersonalisation of regulatory frames such as intellectual property and the new potentials for subjectifying law as no longer a commodity of the rich. ${ }^{33}$ In addition, a critical theoretical approach better explains why law's agency by transforming into a more accessible legal process, will provide a practical space to realise the possibilities for new law as a community resource. In attempting to better explain how markets embed/disembed, how commodities become fictitious, and how law is complicit in exclusionist property arrangements, the suspension of critical communal beliefs and fundamental social imagination is juxtaposed against the resistance of contesting collective consciences and the countermovements they spawn.

All this leads to a novel way of viewing law's regulatory relevance.

However, before the analytical journey proper, we must make clear our appreciation of its central signposts: original property and new law.

\section{NEW LAW AND ORIGINAL PROPERTY}

In order to speculate on law's future in new market arrangements that challenge the current nexus between law and property, it is necessary to reflect on the nature of property in times of social and market transition. We envisage property not necessarily as a thing, or as a right, or even as a material relationship for social or cultural identity. Property is a

33 Teubener (2010). 
continuum which ranges from general good to delineated and individualised benefit. It is not reliant on law's designation of rights of possession and ownership, beyond the realm of commodification. It is at the same time a mechanism for impoverishment and for great wealth generation. It moves from a socially embedded phenomenon, to a disembedded fictitious commodity, although as we explain later, this may not be a simple unidirectional phenomenon. In today's market economies, property has become essentially a product of law, but in its original form is not dependent on legal legitimacy. Above all else, the form that property will take along this continuum is crucially influenced by seismic shifts in social, economic and political consciences at particular historical epochs. ${ }^{34}$ Such cataclysms are the focus of our three case studies.

Law as a regulatory (if mechanical) determinant for markets and for property within markets has expressive and facilitative functions. Primarily expected of public law, but we say it should be even more so for private law, are instrumental techniques to delineate property rights and obligations. In addition, though too often underplayed in their significance, both forms of law offer some broad normative principles around which market and social relationships can be established for the general good, ${ }^{35}$ while at the same time creating strict methods of enforcement, giving law its practical bite. In this way, legal mechanisms such as contracting are performing a central role in the reactionary but certain development of economic orders that depend on property rights and obligations.

The future role of legal regulation within markets now constructed and operating through radically different power relations (see Chapter 7), is a theme which the following analysis will critically evaluate for the purposes of understanding social embedding and power dispersal. It will be asserted that in restricting the transition of law as a communal resource (developed in Chapters 6 and 7), the law/property nexus currently operates as a mechanism of inclusion and exclusion for wealth creation as a consequence of property possession. This need not be so. Even profound critics of the notion and exercise of property, such as Pierre-Joseph Proudhon, of property is theft fame, celebrate the social value of contracting where citizens willingly negotiate their liberty for

34 Such as the invention and proliferation of the internet.

35 The notion of general good as we see it is a natural bi-product of markets becoming more socially embedded (see Chapters 6 and 7). 
the benefits of orderly agreement. ${ }^{36}$ Our case studies of market power dispersal will reveal later, as it engages property that the time for law's transformation from commodity to community is here and now.

Foreshadowed in the preface, globalisation is both a positive and negative context in which market power relations have recently dispersed (further, see Chapter 5). The current era of globalisation has radically reordered how societies interconnect, and the role law plays in the process of social bonding. This book exists in the context of globalisation, having a particular interest in the intersection between law and society in states of change. The internet information revolution, for instance, has radically facilitated the economic and political reach of globalisation and left the conventional relationships propagated and maintained by the law/property nexus in the dust of change. What this means for the regulatory future of law depends on how law and property continue to transform (see Chapter 7).

Free-market capitalism has antipathetically relied on law to facilitate the determination of exclusive property arrangements in market settings where possession comes at a price. It could be argued that private law in particular was co-opted within the capitalist economic mode so that law became a marketable commodity and as such advanced the interests of the capitalist client through ensuring the exclusivity of property transaction. A dominant capitalist world economic order depends on traditional property arrangements offering economic power through exclusive access to what the law designates as property rights, and enormous opportunities for wealth creation through the exclusive transaction of possession. However, in similar market conditions which are now stimulating rather than resisting a dispersal of power to previously weakened market stakeholders, the ability to generate wealth and power is no longer solely situated in limited private property rights and relationships, but through information and its reach. The creation of information, its mining and access can generate wealth and power, independent of one's social or economic location. More importantly, internet information and knowledge exist in a spatial and temporal stratosphere that conventional state-based and international legal enforcement frames are now largely powerless to grasp, contain and regulate. In the case of workforce and trade we are also witnessing, through conditions such as unsustainable socio-demographics, and the rise of grassroots resistance, novel market

36 Proudhon, P.J. (1840), 'What is property? Or an enquiry into the principle of right and governance', in D. Kelley and B. Smith (eds) (1999), What is Property, Cambridge: Cambridge University Press. 
conditions for revaluing essential commodities such as labour and land beyond the money price they can command. Aligned with the dominant economic model, the emergence and growth of global cities is creating new strains on traditional communal bonds, and forces of social exclusion denying responsible dissent are seizing law as a violent retributive response to terror. As part of such major market/social transformations, the book asks where is the future of law in ensuring that the orderly transition of property will be for and not against social good?

What makes our critical project unique is the manner in which we analyse the challenges posed for law by returning to considerations of original property. The appreciation of property which emerges out of the massive shift in collective consciousness regarding, for instance, access to internet knowledge, and the nature of property in the information economy itself, while it could be seen as new relative to exclusionist copyright-style property, is in fact original in form. We say here original in the sense that it has returned to more socially embedded (and in that sense no longer fictional) property arrangements - original in that it can be seen as property pre-dating law's intervention to set inclusive/ exclusive delineations of access and usage - original in that it is not linked to either state or market incentives that artificially commodify and value - original in that neither rights to ownership nor possession are prevailing environmental determinants which give it form. Through such an understanding of property as social relations (see Chapter 6) its pervasive immorality (linked to impoverishment of the many) is dissipated, thereby rehabilitating original property from Proudhon's abolitionist necessity.

What had happened to property by the time it became the evil feature of governance and economy which Proudhon condemned? In Proudhon's critique lies the essence of our conceptualisation of original property. Polanyi, like Proudhon, identified the fictitious nature of property exponentially evolving the more property markets strayed from their essential social location. ${ }^{37}$ So the first indicia of immoral property is its disconnection from general social good. In fact, while Proudhon idealised the virtue of poverty, he attacked the means of impoverishment such as inherited property from the perspective of its class-favouring essentials.

Proudhon argued against political conditions perpetuating three principles that violated social justice: sovereignty degenerated into despotism; the inequality of wealth and rank; and property. The countervailing

37 Much debate has been generated in the field of economic sociology about the use and application of disembedding. See the debate summarised in Krippner, G., Granovetter, M., Block, F. et al. (2004), 'Polanyi Symposium: A conversation on embeddedness', Socio-Economic Review, 2, 109-135. 
view of scholarship at the time supported the inevitable division of property to ensure social survival. Even if the purpose of such division was public utility, for Proudhon this was little more than state confiscation for the benefit of a political and economic elite. In the process of division lie two more features of property which, in returning to its origins, must be shed - social divisiveness and economic/political dependency.

Lawyers in their dealings with property rights as justiciable arrangements claim that they separate property from political considerations. Proudhon scoffed at such unsupportable justifications for the law/ property nexus. Instead he proposed to disentangle three legal traditions that had merged into the genitive which came to classify the nature of property as selective wealth. Property, possession and prescription merged into a simpler understanding of possession by right of proscription. In this sense was revealed another important feature of property away from its origins in social location; the activity of law to prescribe possession and ownership into limited rights for commodity benefit. Otherwise than to face Proudhon's abolitionist demands due to its immorality and injustice, the property/law nexus as the mechanism for alienable distinction (particularly under any discriminatory rights discourse) needs to be radically repositioned from maintaining the inclusion/ exclusion barrier to access and use.

Proudhon spent much energy in What is Property challenging conservative interpretations of the origins of property. These included theories of occupancy, theories of possession as the cause of property, and the derivation of property from labour. In conceptualising original property to accord with Proudhonian thinking, such approaches need to be interrogated and dismissed. Proudhon attacked original occupancy as deriving rights from historical accident. The argument that possession was the product of some positive law that made some distinction between real and theoretical possession, was for Proudhon equally a product of blind coincidence. This is an important understanding when turned in the direction of intellectual property protection and claims to possession of intangible knowledge through some legally legitimated individualised right, even if this relationship is only limited to contract rather than property law terms. Because of what Proudhon came to understand as the irreversibly socialised forms of production, capital and human equality, property as some causal product of labour was no more than the acceptance of the inherent inequalities of the labour force which could never naturally result in just and free benefits to property. Commending this view, our search for what is original and morally defensible property cannot be satisfied by a definition which suggests the natural product of 
labour as its source, ignoring claims arising from possession, or as the inevitable outcome of occupancy.

Dissatisfied with any intellectual justification that did not require concessions to bourgeois inequity, Proudhon concluded that property was impossible and nothing, being derived economically from nothing, and destroying productivity in its exclusivity and power to disembed. Property is theft because it deprives men of the legitimate product of their labour. It is 'homicide' because it disenfranchises men from their limited heritage (the earth), and it is tyrannical in the way it negates equality and conspires with political forces to institutionalise injustice.

Proudhon was not a fatalist about the future of fairer and more just social conditions now endangered through property, and in his concluding chapter in What is Property he predicted and indeed celebrated the 'march of humanity' through sociability, justice and equity. We share his belief in the inevitability of social good and the achievement of justice through communal resourcing in which law can have a productive role. We diverge from an abolitionist argument, preferring a return to original property within market conditions such as the information economy, because they can provide a much more federalist and inclusive engagement between property and law. Like Polanyi, the march as we see it is from those market economies which disembed from their social value, to market communities ${ }^{38}$ which enjoy property beyond its exclusionist commodification. Like Proudhon we are not looking for an anti-legal, anti-political community, but share with him the desire that the community which benefits from a return to original property is reflective and critical of this transition, and we provide a legal frame on which this might rely. Property, being a seductive and successful wealth generator, can slip back into exclusionist arrangements even in more equitable market conditions unless strong normative and procedural frames such as law can establish and maintain clear requirements of obligation and duty which promote rather than pervert social good. This is a realistic and indeed a historically legitimate role for law which preceded its complicity in disembedded capitalist market economies. ${ }^{39}$

The interrogation of property and law which follows has a distinct normative purpose. The book is as much an argument against the

38 It is important to clarify that the communitarian discourse in this book, and the place of law as a communal resource, is squarely located in re-embedded and socially sustainable market conditions where power dispersal is more equitable and transparent.

39 Such as in Hughes, G. (1996), 'Communitarianism and law and order', Critical Social Policy, 16 (49), 17-41. 
inevitability of rational self-interest connecting law and property, as it is a plea for law's relevance as a transformative agent for social good. The radical transformation in the nature and reach of property across globalised internet communities, for instance, offers both risks and opportunities for the realisation of social good. Proudhon declared property is theft, but not so possession. We see a revised role for law in democratised possession (through wider and freer access) being a dynamic, more equal and truly liberal use of and access to property as a resource for a general good. Achieving property as a social bond rather than a disembedding commodity, has powerful ramifications for the determination and attainment of social good. The intriguing alternative title to What is Property 'An inquiry into the principle of right and of government' - suggests the need never to lose sight of the negative and positive potentials of the law/property nexus to influence the just achievement of communal benefit and thereby more just and fair governance in a globalised market world.

\section{DISENTANGLING POSSESSION FROM PROPERTY?}

A foundational rationale for private law as we currently know it ${ }^{40}$ rests on its ability to unite possession with property. In so doing law demarks rights to property and the enforcement of its commodification and value, sometimes employing public law enforcement if breaches of obligation occur. Through a commodity-based delineation of property (rather than as wider social forms and obligations), the wealth and power at the heart of the current global economic model are generated and maintained. However, this conceptualisation of the law/property nexus is both challenging, and being profoundly challenged by, the emerging market conditions such as prevail in the information economy that operates within the counter-narrative that 'possession is for all, property is for none'. ${ }^{41}$ The market conditions enabling the information economy are such that individuals can gain access to new forms of intangible (intellectual) property, ${ }^{42}$ in a form of transient possession which is of

40 Property has been remarked to be a critical component of English private law: Burrows, A.S. (ed.) (2013), English Private Law, Oxford: Oxford University Press, Ch.4.

41 Proudhon (1999), p. 35.

42 On this point we recognize, if intellectually challenge, the current common law position that knowledge may not be deemed property either as real property, 
itself returning the commodification of property to more original and diversified, communal sources of wealth generation through avenues of internet-based mass access previously unavailable by the exclusionist transaction of property benefits. The very nature of this information property (unlike land and other forms of tangible property, or even conventional choses in action) cannot be easily materially delineated. In turn, law as a legitimator of property as wealth is becoming less able to unquestionably practise ring-fencing through rights allocation such as ownership, and is being called on by a community counter-narrative to eschew its function for determining inclusion and exclusion.

Through the current assault on intellectual property commodification, ${ }^{43}$ the property/wealth synergy has come full circle. Markets alienate and control/restrict property thereby changing its form and accessibility. The law overlays this process with a mask of proprietary rights. Yet the intangible and inherently ethereal nature of what has been termed by law intellectual property confounds the alienability history, and we now see active resistance both to the law's determination of knowledge and information as saleable products, and to law's enforcement of what are all but ownership rights through devices such as patent and trademark. This cycle, we will later argue, can be seen as three stages of embedding/ disembedding/re-embedding property from (and back to) social good, a process in which law plays a significant role. ${ }^{44}$ Following Polanyi, property has become artificial, fictional in form due to its capitalist transition. Proudhon argued more dogmatically that property was impossible and an abomination in the hands of the bourgeois state and its beneficiaries. As such, his argument would conclude that the contemporary commodification of property cannot stand. We will later explore how a counter-narrative on property, a new community consensus about

a chose in action, or any other legally designated property right, outside contractual arrangements.

43 Coriat B. and Weinstein O. (2009), 'Intellectual property rights regimes, firms and the commodification of knowledge', CPLE Research Paper No. 17/2009; Troutt, D. (2004-05), 'Portrait of the trademark as black man: Intellectual property, commodification and redemption', Davis Law Review, 38 (4), 1141-1208; Kapczynski, A. (2014), 'Intellectual property's leviathan', Law and Contemporary Problems, 77 (4), 131-145.

44 As expanded later in Chapter 6, we take the Polanyi proposition concerning double movement to involve a market shift from the social to the fictitious, met by a reaction from state instrumentalities or the market itself to compensate for the negative consequences of the disembedding process, and outside and beyond this a counter movement to radically reposition the market and its stakeholders. 
access and enjoyment, and some profound dispersals of market power facilitating this and benefitting from it, are revealing the original (or some may say 'truer') nature of property in an environment where territory and time no longer offer shape to property markets.

Facing and ineffectively resisting a wave of community consensus selectively demanding unfettered (or at least much less restricted) access to information and its uses, law is being forced away from treating the issue of access as the point of wealth generation (access being what sets the perimeters of wealth and power prior to the valuation of the thing accessed). Seen in this light, law is no longer ineffably capable of benefitting the few against the many, when the structure of society is now experiencing more equitable market conditions where the contested conscience 45 is strong.

As a note of caution here, it would be misguided to assume, and misdirected to conclude that the collective conscience which is behind unauthorised access to internet information is united in its motivation and a singular attack on exclusive private property rights at large. Individuals within this conscience download for different reasons and with often different priorities. In addition, while unauthorised downloading may have been morally and legally neutralised within the contested conscience, many of those comprising its dynamic would alternately support and expect law to prescribe other exclusionist property arrangements in fictitious markets of land, labour and money.

That said, against what we argue is the inevitability of the transformation in law, property and market societies, each facing epidemic challenges to property as social relations, such as information economy exclusion, the critical analysis of law's regulatory relevance will need in our view to engage the following issues:

(a) How will law situate itself within markets for property which have returned to their more original communitarian form in terms of power dispersal?

(b) How in such changed market environments, involving a shift in the essence of property commodification, and a falling away of exclusive property rights and benefits, will the relevance of law change given that traditionally property law is based on priced access and delineation? How can law revamp its relationship with property

45 It is important here to remember that many collective consciences can make up a living society. Some of these compete with each other for influence over their transition and eventual reformulation. Therefore, it is not only within a particular collective conscience that one should search for the sources of change. 
sufficiently to co-exist with this transformation in property access and arrangements? Specifically, without impeding the natural return to more original property arrangements, how can law as a communal resource ensure an orderly transition so that old modes of exploitation are not replaced by new versions of the same?

(c) What will be the new regulatory role of law in new markets for property access not driven by commodification, bearing in mind that the transition in property arrangements through market power dispersal could be even more vulnerable to self-interested exploitation than the discriminatory but disciplined legal relationships it replaces?

(d) How will property in its more original form (and the law on which it may come to rely for orderly communal benefit) sit with the current law that seeks to delineate property rights during the strained and disessential period of transition?

This project calls for the reimagination of property and its markets in space, time, and more importantly law's dynamic within a variety of contesting collective consciences. It is not particularly about property or law or even their nexus, but it is instead concerned with achieving the orderly aspirations of a counter-narrative which is forcing law's current reactionary role in the commodification of property to transform, and thereby assist in its own regulatory overhaul. Such a process is neither unrealistic nor utopian when one reflects on the normative foundations of private law and their reflection of social good. What is now necessary, rather than a legal revolution, is a logical return of regulatory practice to original principle. In addition, this transposition for law will not require the nature of property to change. With or without law, property as more embedded social relations is becoming, and should always have been recognised as forms and functions which enable the enjoyment of freer notions of access as possession for all. ${ }^{46}$ Fuel for a root and branch contextual reformulation is the return of market economies to the social (discussed in our case studies), a process well under way in today's information economy, in the challenge to the global city, and the

46 As indicated later (see Chapter 3) an ungoverned shift to intellectual commons promotes the real danger that values of information integrity may be impossible to guarantee - see for instance Green, S. (2002), 'Plagiarism, norms and the limits of theft law: Some observations on the use of criminal sanctions in enforcing intellectual property rights', Hastings Law Journal, 54 (1), 167-242 at 205-207. 
resistance to trade imperialism, and the channels for power dispersal that each of these represents.

\section{PROPERTY, EMBEDDING ECONOMIES AND MARKET POWER DISPERSAL - ANALYTICAL THEMES}

Before examining the interconnection between property and essential market conditions in the drift from the social it is important to confront the emerging critique of embedding as an analytical tool. Gemici says that Polanyi's embeddedness concept, despite standing as his most famous contribution to market analysis, has been a source of enormous confusion. He argues, through a close textual interrogation of Polanyi's writings, that this confusion stems from a central fracture in Polanyi's thought, thereby creating an ostensible contradiction:

- Economies are embedded and enmeshed in institutions.

- Market exchange and market economy are self-regulating and disembedded.

Gemici approaches this contradiction by declaring that Polanyi uses embeddedness as an analytical construct to discern the changing place of economy in society throughout human history. In so doing he employs embeddedness to specify the degree to which economy is separated from the rest of society. In such a way, the embeddedness concept represents a mirror for understanding how economy becomes dislocated from its organic social bonds. As an example, market economy is regarded by Polanyi as the first disembedded economic system in history. Accepting this analysis as restricted to the institutional comparison of market systems to other economic systems then embeddedness is just a methodological principle positing that economy and society can only be analysed through a holistic approach, that being to understand the divergence/convergence of economy in society under any historical market condition.

Persuasive as seems the division of embeddedness into methodological and theoretical purposes, it may not be necessary to limit the utility of embeddedness to comparisons of markets with social economies. Recognising social bonding as a complex web, one crucial area of which is economic relations wherein the market is a key institution, then embeddedness can be applied in analysing many other situations of social 
bonding, private property relations being an additional field for evaluation in terms of social location. Despite Gemici's reservations, embeddedness may be returned to a simpler meaning of social location and positioning, recognising however that within this simplicity resides the question, what do we mean by the social ${ }^{47}$ We will elaborate on the social and its connection to communities in our case studies as well as the final chapters.

Gemici argues that embeddedness is not necessarily a variable or a characteristic of economic systems. Polanyi viewed markets and economies as both capable of social location and thereby socially beneficial. Therefore, embeddedness requires, whether it is markets or economies that we are comparing with this measure (or any other frame of social bonding), that the evaluation must be holistic against a range of forces, which work towards or against bonding. ${ }^{48}$ Consistent with this position Polanyi proposes a thesis about the impossibility of separating economy from society because all economic systems are embedded in social relations and institutions. While the economy inhabits a separate and autonomous sphere under capitalism, it is enmeshed in society under pre-modern economies in such a manner that studying the economy apart from 'the tissue of relationships' that constitutes 'the reality of society' would be erroneous. ${ }^{49}$

That Polanyi envisions the market economy as separate from social institutions, functioning according to its own rules (being more mechanical social arrangements), only goes further to confirm that disembedding social processes from their social bonds tends to create in these processes a dependency on externalities such as an artificial division of labour for their essential functioning. This understanding favours Gemici's interpretation of embeddedness arising as a gradational concept, and that the totally disembedded economy is not possible, but some economic arrangements are more absorbed in social institutions and relations than others. In Polanyi's arguments, there exists an almost unidirectional and relentless assumption of the market moving away from the social. Again,

47 This concept will be developed more fully as the three case studies later unfold.

48 As economic actions within the market are just one category of a wide range of social interactions, see Perry-Kessaris, A. (2011), 'Reading the story of law and embeddedness through a community lens: A Polanyi-meets-Cotterrell economic sociology of law?', Northern Ireland Legal Quarterly, 62 (4), 401-413.

49 Gemici, K. (2008), 'Karl Polanyi and the antimonies of embeddedness', Socio-Economic Review, 6, 5-33, at 8. 
while recognising that such a dynamic at least is likely to be affected by push/pull factors which influence market development and transformation, it is enough to observe stages and states at which market societies and social disembedding are empirically undeniable. Relative to particular market forms and social needs, the drift to disembedding will have differing rates and even peaks and troughs. As Ebner identifies, Polanyi advanced a two-fold consideration of embeddedness: as a representation of the connection of markets to the moral fabric of society, and as a political term that refers to social reform and the regulation of markets (in particular regarding fictitious commodities). ${ }^{50}$ As has been observed in the recent near collapse of the global financial industry, the reform process as a move toward market remoralising through closer social governance cannot be left to the vagaries, even treacheries of selfinterested self-regulation.

\section{REGULATORY REFLECTIONS}

Taken as a given that global governance as a hegemonic project is interested in the viability of market economies such as the original and unchallenged information economy (see Chapter 3), then the role of law in contributing to the orderly transition of property arrangements in this new era of more equitable market conditions should be a crucial field for regulatory reflection and socio-legal scholarship. Unfortunately, much of the discussion of law's place has been restricted to the refinement of enforcement or the generation of new regimes for effective commodification. This text returns to the principles on which private law rests, to redirect this analysis away from functionalist economic conjecture on the protection of prevailing property arrangements. It provides a new way of appreciating law beyond the commodification of property and towards more sustainable understandings of property relations as the product of legal regulation with an interest in more general social good.

In the case studies of contested consciences, the analysis to follow will argue that, through the critical application of social theorising which explores relationships between law and social transformation driven by shifts in the collective conscience that anything but a reactionary positioning of law in contexts of social change is functional in terms of social good. We will employ law's fundamental, historical relationship with

50 Ebner, A. (2010), 'Transnational markets and the Polanyi problem', in C. Joerges and J. Falke (eds), Karl Polanyi, Globalisation and the Potential of Law in Transnational Markets, Oxford: Hart Publishing, pp. 19-41. 
private property arrangements and the space in which they operate, to explore the possibilities for law as a productive agent of social change in the context of the morphing collective conscience surrounding appropriate and sustainable access to essential social goods such as knowledge and fair and viable market benefits.

For those who would argue that the practice of law is essentially an individualist project, we would reply that in such an evaluation resides a reason for law's current market idiosyncrasy. With the commodification of law as a disembedding market technology (see Chapters 6 and 7) the link between law and social duty has been lost. The commodification of law is accompanied by a diminution and devaluing of one of law's most primitive functions: to ensure that social duty is respected. In relation to exclusionist property rights, law has crucially delimited those who can claim duty and expect its enforcement. We will later argue (see Chapter 6) that law as a process redirected back to a broader base of duty and obligation promoting good for the social as much as the individual, can enable far wider opportunities for inclusion in the conciliation and mediation of interests beyond the protection of private property rights (see Chapter 7). If we are to take this assertion into the realm of social facts rather than dogmatic anticipation, it is necessary to theorise law as a social change agent.

In his seminal essay 'Rules for the distinction of the normal from the pathological',51 Emile Durkheim advanced the following analytical approach when understanding the nature of social facts such as law and property:

Having established by observation that the fact is general, [the sociologist] will trace back the conditions which determined this general character in the past, and then investigate whether these conditions still pertain in the present, or on the contrary, have changed.

Durkheim then went on to employ this reflective historical approach to understanding the economic state of peoples in Europe at the time. In determining social solidarity, Durkheim saw law as a social fact obtaining its relevance in specific social location and evaluation. After examining society in flux he proposed three rules for the analytical utility of general social facts:

51 Durkheim, E. (1982), The Rules of Sociological Method and Selected Texts on Sociology and its Method, New York: Free Press. 
- A social fact is normal for a given social type, viewed at a given phase of its development, when it occurs in the average society of that species, considered at the corresponding phase of its evolution.

- ... the general character of the phenomenon is related to the general conditions of collective life in the social type under consideration.

- This verification is necessary when this fact relates to a social species which has not yet gone through its complete evolution. ${ }^{52}$

For the purposes of the analysis to follow we will assert as a social fact that law has performed an essential role in the commodification of private property which is vital to a capitalist economic model. In that sense both law and property may be normal but only if certain market conditions prevail such that they satisfy a dominant social consensus about each and both. Using intellectual property law and the information economy, the control of terrorist dissent through social exclusion, and the corrupt distortion of trading imperialism where the tyranny of patent and trade mark and the oppression of trade liberalisation enslave South World markets, we will show how law and its regulatory power have governed access to market property in ways which have ensured value to a limited class of property owners and licensees. In addition, we will reveal how law's regulation of exclusionist space such as the global city is leading to market disembedding and power dispersal now ripe for collective counter-consciences. We will progress to explore, in Chapter 3 for instance, the recent phenomenon of unauthorised information downloading (a social fact in the digital age) in order to:

(a) understand how notions of property are changing under more dispersed market power conditions;

(b) explore the ways in which changed notions of property, and the rights and obligations associated with these notions, are putting pressure on the presently existing connection between law and private property; and from here

(c) chart a possible course for law as a positive agent in social change.

Durkheim is also useful to our analysis for the manner in which he theorises social order and its dynamics. It could be argued that the relationship between contract law and commercial obligations, for instance, establishes, if in sometimes very discriminatory ways, market arrangements which are predictable and therefore orderly. Currently, however, we are witnessing a generation of information consumers who

52 Durkheim (1982), p. 97. 
are flouting conventional property access arrangements and thereby revealing law's impotence to hold back this wave of change, and protect the limited property rights which intellectual property law sets out to confirm. Durkheim not only offered a way of understanding the different forms of market order in property arrangements, but more importantly for us, a way to appreciate transition.

Durkheim observed that in the case of theft or the misappropriation of property, these two crimes differentially offend the altruistic sentiment to protect other people's possessions. ${ }^{53}$ However, using the soft/hard consciousness analysis, if there is a shift in the collective feelings of society so that the weaker state of consciousness (which, for example, once said that access to information should be free and open to all) moves to dominate an earlier stronger consciousness (that information can only be accessed at a price levied by its owner), then social order itself will reposition. Durkheim then theorised, by employing notions of crime and penal law, what happens in such circumstances to the social facts, like law, which once preserved the boundaries of that earlier social consciousness. Our analysis employs such a theoretical progression to explain a change in the function of law as a community resource rather than a delimiter of wealth creation where property arrangements are in revolution.

In his distinction between the normal and the pathological, Durkheim was presenting a parable of change agency. A social fact in the context of the evolution of societies requires that the boundaries of any social conscience are not impervious to the influence of contested consciousness. Durkheim determined under certain social conditions that challenges from within the conscience collective can push the boundaries of any countervailing conscience.

In his crime/penality example, Durkheim anticipated that a certain level of crime is normal in society so that the strength of the collective conscience can be tested and reaffirmed. On rare occasions crime can be a functional agent of change, forcing the boundaries of the collective consciousness to shift and change. In our analysis, the download generation is acting in ways which might otherwise be deemed criminal to test pre-existing property rights and challenge the law's role in retaining them.

$[\mathrm{N}]$ ot only do law and morality vary from one social type to another, but they even change within the same type if the conditions of collective existence are

53 Durkheim (1982), p. 99. 
modified.$^{54}$... Yet for these transformations to be made possible the collective sentiments at the basis of morality should not prove unyielding to change and consequently should only be moderately intense. If they are too strong they would no longer be malleable. ${ }^{55}$

We will develop detail concerning how in re-embedding global market economies the traditional functions of law, particularly private law, are under strain. What Durkheim conceived of as the collective conscience, is in radical transition when it comes to appreciating property arrangements which govern information access in the digital age and the way in which market economies function internationally. It is now more than unlikely, for example that through employing the conventions of copyright, and exercising the sanctions of theft, law can hold back the tide of unauthorised information access and protect limited and exclusive private property or licence rights. It is also no longer certain, if it ever was, that the law can distinctively discriminate between legitimate and illegitimate market relationships.

If unauthorised information access is to be criminalised and coded as theft (further discussed in Chapter 2), then its functional dimension should not be ignored, so labelled or not.

[c]rime itself may play a useful part in this evolution. Not only does it imply that the way to necessary changes remains open, but in certain cases it also directly prepares for these changes. ${ }^{56}$

Where does this leave law? The book's argument is in part designed to salvage the relevance of law as a force for maintaining the orderly transition of the collective social conscience and its market objectives (see Chapter 7).

\section{NEW LAW AND SOCIAL GOOD}

To redirect law's regulatory focus away from exclusionist private property arrangements or hegemonic delivery of justice services, the normative framework promoted through legal regulation should not merely reflect some externalised mandatory measure. In particular, it should not

54 Durkheim suggested that a diversity of social consciences may result out of variations in immediate physical environments, hereditary antecedents, and social influences.

55 Durkheim (1982), p. 101.

56 Durkheim (1982), p. 102. 
be calibrated by a structure of privately created norms largely or only relating to the beneficial entitlement of parties selectively included on the basis of their claims to property. Proudhon took questions of the normative foundation for property to revolve around the distinction between property being exclusive or inclusive, measured against notions of ownership versus possession. If ownership were to be recognised as universal across society, then the exclusivity of possession would fall away and there would be no need for the law as its protective agent. In such a context the normative framework for property becomes essentially social relations of equity and universality, not exclusivity and scarcity.

Because Proudhon had little time for law, beyond his interest in contracting as evidence of liberty and dignity, his analysis did not assist in exploring how law might act as a re-embedding agent for property back to the social. Indeed, there are later theorists who also are circumspect about law's capacity to bridge market transition. For instance, Hugh Collins employs Teubner's view that the law remains normatively separate from other regulatory systems even if it retains the potential for cognitive interconnection:

Legal operations, by their very operative closure and, as a matter of principle, cannot reach out into domains of non-law. As a result law can only reconstruct its environment internally through closed self-referential operations. This internal reconstruction of the external world is never identical with the events as they happen in the external world. Even if their substance appears to be identical they are different because they are non-contextualised ... Calculations of costs and calculations of power, policy arguments and scientific constructs ... all become strange hybrids which are now, however, the sole responsibility of the legal discourse. ${ }^{57}$

Our view of new law is that under the right market and governance conditions (which it further facilitates in alignment with repositioned private property arrangements), it can promote social good along with new wealth creation opportunities that possess communal utility rather than individualised exclusive benefit (see Chapter 6). As outcomes for new law, wealth creation and more liberal access to property need not be mutually exclusive within contemporary market economies such as information economies. The qualification is that as property returns to the social, wealth may also become more socially determined. And as property returns to the social there will arise, through its intertwined

57 Collins, H. (1999), Regulating Contracts, New York: Oxford University Press, p. 55. 
relations with law, pressure on law to transform from a force for scarcity to a force for communal utility.

The new exigencies offered through the information economy to return law to a more communal utility are just some of the forces for transition which the book will go on to explore (see Chapters 4 and 5). It is our argument that where property is very broadly conceived as social relationships, and the collective conscience concerning rights versus access vigorously contests commodification and demands social access, then law can find an important role in regulating for, rather than resisting property's re-embedding.

In its broad regulatory reach, law can be viewed free of the state and state interests. ${ }^{58}$ Law can work towards facilities, processes, relationships and outcomes wherein parties undertake equivalent and reciprocal obligations to one another, and each reserves unto themselves a measure of rights, liberty, authority, and eventually property that is currently conceded through vulnerable and dependent property inequalities. Under existing notions of social consensus the individual gives up a greater measure of freedom and authority than the part s/he reserves, in the anticipation that illusive benefits will eventually accrue in a more balanced fashion, or that inequality is tolerated because the alternative to distorted social contract may be perceived by that party as a worse outcome (charted by poverty). Throughout the case studies to follow, we apply the analytical device of suspension to explain how disempowered market stakeholders are induced to tolerate the unfair consequences of disembedding. A loss of social imagination and a disbelief in the capacity to resist and turn the tide give suspension its essential positioning in the disembedding momentum. Against suspension and disembedding Polanyi believed that the state through law can initiate the conditions in which equitable movement can emerge, but if law for individual benefit takes over then politics for social good will eventually be withdrawn in favour of exchange market individualism, and self-regulating self-interest. In terms of the social good represented by enhanced access to the enjoyment of property, then some of the fundamental building blocks of law's contemporary property arrangements need surgical rethinking along with a reinterpretation of the role of the state as a potential re-embedding force (see Chapters 6 and 7).

58 In the context of freedom of religious beliefs and neutral laws, see Marin, K. (1991), 'Employment Division v. Smith: The Supreme Court alters the state of free exercise doctrine', American University Law Review, 40, 1431-1476. 


\section{WHERETO THE STATE AND ITS INSTITUTIONAL AND PROCESS RELATIONS WITH NEW LAW?}

Durkheim spoke of the state as a 'social brain' that 'thinks for society' making evaluations related to but beyond those that individual citizens can establish, and geared to a collective interest. ${ }^{59}$

Currently the regulatory essence of law remains inextricably connected to a self-interested regulatory state mode, and to exclusionist and fictional market economies. Along this line the book's argument will advance returning law to a principled regulatory purpose and consider how law in principle, relationships and outcomes can better develop as a force for social bonding and common good in a world where current political economic and social models are under fundamental strain.

The nexus between law and property, in the context of today's neo-liberal market economy, is represented by exclusive property frameworks that the law creates and protects. Our later discussion of repositioning law to help rather than hinder pathways for redistributing market power away from the dominant neo-liberal model (see Chapters 3 and 7) belies two assumptions. First, that there is something socially destructive about the neo-liberal economic model that should be rejected and resisted. Adopting Polanyi's idea of fictitious commodities, the neoliberal model of commodification and the disembedding of the social through giving preeminence to economy, relies on the disempowerment of non-propertied market players. Using Polanyi's fictitious commodities as our starting point, we argue through our case studies to follow that state-sponsored law is used to cloak the fictitious with the real by commanding rights and imposing obligations in market property arrangements. Further, law as a contemporary market force externally imposes a market significance on otherwise social units of production (that have been severed from the community), so much so that these fictitious commodities have the semblance of what is real and actual.

This process, we term, propertisation. A by-product of propertisation is social dislocation, where society develops a sense of learned helplessness in that it is no longer able to assert the essential values of its bonds except in terms of economy. In such a state the social imagination about returning property to a more communal valuing is suspended in the face

59 Cotterrell, R. (2013b), 'Transitional networks of community and international economic law', in A. Perry-Kessaris (ed.), Socio-Legal Approaches to International Economic Law: Text, Context, Subtext, Oxford: Routledge, pp. 133-149 at p. 144. 
of market disembedding. As society conceives of its values in terms of the market, the common sense concerning property that once weaved its way through grounded communities is suspended. Over time, society tends to forget that there are ways of accessing property other than on commercial terms. Such amnesia makes it possible for those claiming property 'rights' in the market to convert the social into the commodifiable, while those who are unable to afford law's authorisation and enforcement, or pay fees for service, remain excluded from property access and benefit.

The state, often through fundamental misrepresentations of its regulatory objectives, aligns with the law it sponsors in advancing propertised and commodified interests in those private property relations which determine market economies, and thereby underpin hegemonic governance. The challenge for repositioning law outside this degraded sponsorship/servile relationship, is to address exclusionist governance and market interest imbalances, by levelling out in particular property arrangements like issues of obligation, rights and actionability. Law needs to have a more holistic presence in this regulatory endeavour if it is to cover an expanded interest base and return to function as a communal resource. Law's expressive function must clearly declare a determination to redress and disperse market power imbalance through enlivening new routes of access to property and different measures for property valuing.

However, this is much more than some sort of legalised patch-up job. For instance, employing a rejigged rights model endorsing and enabling more universal access to the information economy, while seductive, is not the answer for law as a change agent. Individualised rights as a practical legal application are currently inextricable from property relations as an alienated market benefit and an exclusionist governance power frame. If rights protection means ensuring the rights of the propertied against the just claims of the propertyless, then it is little more than an alternative arena of oppression (see Chapter 7). In this regard the intersection between public regulation and private rights reveals opportunities for the state to stimulate or to responsibilise private property arrangements, flexibly constructed and contained through private law and public justice. The reconsideration of the role of intellectual property law is an important case in point (see Chapter 6).

As suggested earlier, we see dangers in the transition to original property and the realisation of transformed market arrangements such as underpin the information economy as a general good. If this transition occurs in an individualised wealth creation consciousness where economic growth is prioritised over all other social goods, then there is 
nothing to stop new forms of discriminatory commodification emerging even after the breakdown of inclusive/exclusive property rights frames.

These dangers will be exacerbated by the state re-enforcing (through law among other mechanisms) its alliances with those who now benefit from exclusionist property arrangements, and who ensure these with the state's political assistance by maintaining market power imbalances through exacerbating the knowledge deficit of other stakeholders. In transnational and global market configurations and networks the influence of individual nation states to perpetuate such market arrangements will inevitably diminish. Numerous non-state standard setting agencies which are emerging and growing in transnational private law arenas depend now on issues such as expertise rather than state endorsement. In turn, the empowerment of civil society through social media is sidelining some of the conventional nation-state governance structures which previously demanded market stakeholder engagement if transactions were to be deemed authorised or legitimate.

In this connection the availability of knowledge referred to earlier for its significance in building mutual interpersonal trust, again assumes great importance ... If people cannot learn enough to be able to interpret other people's viewpoints and (assuming goodwill) to work towards consensus, the alternative is reliance on expertise (on the assumption that experts can close off debate by the superior authority of their knowledge). ${ }^{60}$

In stimulating re-embedding through new law, there needs to be awareness of the dangers of replacing one knowledge monopolist (the state) with another (the expert). New market domains under pressure from competing market consciences regarding the nature of property, with transient regulatory frames (such as the information economy) are most vulnerable to such power repositioning.

\section{DISPERSED POWER IN NEW MARKET CONDITIONS}

One of the distinctive features of globalisation has been its influence over the capitalist economic model. In his recent critique of capitalism and its future, Paul Mason observes:

60 Cotterrell (2013b), p. 144. 
To reduce the distortions - the imbalances - (caused by globalisation) you have to suppress the normal form of neo-liberal growth. ${ }^{61}$

Mason provocatively asserts that the world's vast majority have gained nothing in real terms from capitalism and that this economic arrangement is in terminal decline. Assuming this to be so, and accepting the inevitable impact such change will have on global economic ordering, this text will employ fundamental concepts of law and society scholarship to understand a possible positive role which law can play in the society that will emerge from the economic wreckage that precedes post-capitalism.

In the prevailing global economic model, property and the commercial/ hegemonic power its dominance offers, have through global capitalism mutually reinforced each other's influence for global market dominance. Both private and public law are, in capitalist market frames, essential in the commodification of property, and enforcing its value for those who wish to transact with property interests. Historically this has seen law as a regulator of market value in property rather than as a facilitator of access to property for wider social good. The devaluation of labour, for instance, represents the negative coalition of law, the state and preferred market players.

In capitalist market frames, the free movement of devalued labour has stimulated global economic growth. Without this resource, capitalism would have lacked the essential processes behind production, with work being routinely commodified as devalued property. Under new market conditions emerging out of societies with dysfunctional sociodemographics, the labour/capital nexus is regaining some of its presently diminishing economic and social significance which up until recently threatened further damaging effects on the social embeddedness of labour value. For commercial labour value, countermovement or not, nation states and workers are trapped in a spiral of ever-vanishing labour market power if wage pricing is the primary measure. ${ }^{62}$ Mason argues that a more flexible marketing of information and knowledge offers a way out of this vortex. If one reverts to Polanyi's notions of fictitious commodities (land, labour and money, as he then saw them) emerging as markets removed from the social, the transformation of property in an information economy is a rejection of the fictitious in favour of the use of information

61 Mason, P. (2015a), Postcapitalism: A Guide to Our Future, London: Allen \& Lane, p. 23.

62 Mason (2015a), p. 165: 'The real wonder of information is not that it is immaterial but that it eradicates the need for labour on an incalculable scale.' 
for purposes more closely linked to the social. In this way the contesting conscience advocating more general and uninhibited access offers new opportunities for more sustainable social goods wherein property can return to an economic value serving social good. However, as we suggest in the conclusion of this text, without the more embedded intervention of legal regulation, new pathways of access may in fact produce further inequitable distributions of power in the repositioned market.

As an example of market economies shifting back closer to their social roots and more equitably dispersing power as a consequence, the information economy is the first in our set of case studies and reveals the antithesis of pre-existing property regimes and their intersection with law. Property, particularly if argued as information and knowledge, being a focus for governing social relations now begs questions of whether two main sources of market wealth and power generation (exclusive property and accessible information) can resist destructive market strain, and if so, what will be their impact one on the other in socially embedding market economies?

Our second case study focuses on the control of terrorist violence through social inclusion. It is suggested that if such violence is disentangled from its fundamentalist normative conditions and its predispositions to just that sort of inequitable power replacement which we warned as possible in transitional information economies, it is essentially an imperial and hegemonic project. From that realisation, the analysis focuses on the essential of responsible dissent for communities vulnerable to radicalisation. This vulnerability we advance is as much a market condition, as it might be an ideological predilection. The global city, the site for terrorist violence and violent control responses, is an exclusionist machine relying heavily on the have-not communities being excluded from the proprietor benefits of the haves. The essence of economic exclusion then becomes a force for limited social inclusion offered by the market for terror. Law now offers a strategy of violent retribution and further exclusion. New law as a communal resource will be more dedicated to creating and maintaining pathways for responsible nonviolent dissent, rather than providing the punitive legitimacy falsely claimed through restricting dissent and maintaining the exclusive boundaries against which dissent rails.

The final case study observes that in an effort to prop up a failing global economic order, hegemonic power has during the last century transformed mercantile colonialism into a post-colonial imperial project of free trade. This development model has been at the social and 
economic expense of fragile South World subsistence markets. ${ }^{63}$ The globalisation of world trade has generated a proliferation of corrupt market opportunities. Law, through regimes such as facilitation payments, has massaged the business efficacy of corrupt relationships, and participated in the moral distractions at the heart of notoriously unsuccessful corruption control frames. Law enables the blurring of legitimate and illegitimate market dynamics when key features of free-market resilience (such as competition) are undermined through corrupt market preferencing. The model of global development based on foreign direct investment, combined with corrupted markets, free trade market erosion and dependency, and the tyranny of patents and trademarks, has enslaved South World societies. Through the retaliation of community empowerment movements culminating in efforts to refashion more communal state arrangements, ${ }^{64}$ market conditions for the valuing and utility of natural resources, once raped from disempowered communities, are returning to considerations of social good.

Out of these points of conjecture and contested consciences (information economy, terrorist dissent and social exclusion, and post-colonial trade), the book will speculate on how societies (touched by the legal regulatory institutions and processes of global governance to differing degrees) can respond to the transformation of property in information, communication and trade, when law as a social regulator lags behind these developments. The book uses analytical tools drawn from:

- Proudhon's ideas on property being only possible as a communitarian dynamic;

- the consequent subsuming of the state role as law's sponsor, through freer forms of social contracting and communitarian resourcing;

- the evolution of what Durkheim charts as competing social consensus about access to property benefit;

63 Darian-Smith, E. (2013), 'Postcolonial theories of law', in R. Banakar and M. Travers (eds), Law and Social Theory, Oxford: Hart Publishing, pp. 247-264 at p. 256. Also, Rajagopal, B. (2003), International Law from Below: Development, Social Movements and Third World Resistance, Cambridge: Cambridge University Press, p. 402.

64 Mudacumura, G. and Morçöl, G. (2014), Challenges to Democratic Governance in Developing Countries, Switzerland: Springer International Publishing; Boron, A. and Lechini, G. (2005), Politics and Social Movements in an Hegemonic World: Lessons from Africa, Asia and Latin America, Buenos Aires: CLACSO. 
- Polanyi's thinking around market disembedding and its countervention through law as a communal resource; and

- Cotterrell's formulations of community and the social,

in order to explain the fault lines between property access and its commodification. If law is to resume its Durkheimian potential as a reflection of settled or transitional collective consciences, then our analysis to follow will question how its regulatory focus must move from commodification to more communitarian property engagement. New law as a community resource can umpire the tensions which will inevitably arise during the transition from property rights as money earners to property access as the realisation of the contested community conscience (see Chapters 6 and 7).

Durkheim expressed this differently, but to broadly similar effect, by suggesting that law that has no firm ties to the moral bases of social life has lost its soul and can even seem a dead letter. ${ }^{65}$

\section{COMPETING COLLECTIVE CONSCIENCE}

If law is essentially a social artefact, often torn away from its moorings in the social, then law's force for social change will be dulled the more it operates as a commodity in the abstractions of marketing other fictitious commodities (see Chapter 3).

The complex project of what might be called embedded law creation cannot, for example, rely - as economic analysis of law often does - on abstract models of self-interested rational calculation as a satisfactory basis for understanding the environments to be regulated. Such models are inadequate substitutes for enquiring into real understandings of regulated populations. The process of regulating, even for primarily economic relations, has to take account of varied types of motivations that are supports of social relations of community. These include not only instrumental cost-benefit calculations, but also emotional allegiances, rejections and resistances; as well as reliance on habit, customs, traditions and attractions of the familiar, and also adherence to fundamental beliefs and ultimate values accepted for their own sake. ${ }^{66}$

Essentially consistent with Durkheim's qualitative measure of 'normality', one crucial comparative degree in the empirical research to follow is

65 Cotterrell (2013b), p. 142.

66 Cotterrell (2013b), pp. 142-143. 
the extent to which community consensus divides over the normal and the pathological, how these evolve and where they intersect:

If normality does not inhere in the things (social facts) themselves, if on the contrary it is a characteristic which we impose on them externally or for whatever reason refuse to do so, this salutary state of dependence on things is lost. ${ }^{67}$

Consistent with Durkheim's verifications of social facts, the book's methodology will take three forms. In the first phase we will consult legal narrative to establish the relationship between property law, and the exclusionist commodification of property. This exercise will have a dual function. Initially it will reveal the contemporary role of legal regulation in the determination of property as an exclusive and transactable commodity. Next it will identify the relationships and outcomes in a market sense, which build value into property by restricting access through contrived scarcity. The next phase will be to conduct a comparative case study analysis of different contemporary regulatory approaches as law is directed against the social fact of challenges to property access (information), valuing (responsible dissent), and determination (trade and development).

In the information economy case study, for instance, these may include the prosecution of individual downloaders, suing major internet storage providers, liaising modified shared access arrangements between agents and users, and overseeing industry self-regulation through policing of access by internet providers. The flaws in each of these approaches will be identified in order to preface our later speculation on how law can adapt to facilitate rather than retard the possibilities of a more open information environment. As Mason suggests, at its most basic, law could have a role in this regulatory transition by (through private law) benefitting innovation and (through public law) punishing rent-seeking behaviour. The disembedding process against which new law needs to respond through ordering freer pathways of access is the commodification of information. The double movement parallel we draw originally from Polanyi occurs in combination with other market regulatory forms that exhibit common intent, via more accessible legal processes and institutions, to challenge law's current role in the commodification market. The constructive countermovement (being the province of currently disenfranchised market stakeholders, facilitated by new law) is the

67 Durkheim (1982), p. 104: 'For sociology really to be a science of things the generality of phenomena must be taken as the criterion of their normality.' 
exploitation of already available internet information irrespective of the legal struggle over rights.

Looking at terrorist violence as a consequence of constrained dissent pathways within the social exclusion of the global city we will establish the manner in which law, through legitimating violent control responses and commodifying violence as a medium for the protection of exclusionist property arrangements, sustains the exclusionist market hierarchies of the global city. We will then speculate on why in certain contexts there are emerging violent and destructive countermovements against the underpinnings of the global city, and in response a violent state double movement said to be on behalf of innocent victims. The constructive alternative countermovement here is seen in otherwise non-violent communities and their sub-systems returning to responsible resistance and against terror. The analysis will project on how law and its absence has colluded in preventing the disembedding resistant communities from participating in markets for non-violent dissent, leading eventually to the co-option by authors of the destructive countermovement, of otherwise non-violent communities into markets for violent terror. Law here secures the class domains of the global city and distinguishes fissures between terror and violent control as innocent or blameworthy. Additionally offering a delineating function authorising violent responses rather than communal reconciliation, law endeavours to provide an important legitimating medium in dividing 'us' from 'them' as a feeble answer to a more profound legitimation crisis. The analysis questions how the failure not so much of a compatible consensus but rather of tolerant collective counter-consciences can transform non-violent market options for communicating social change and challenges to the limits of this economic disembedding of communities and the social value of their dissent into terror. From this consideration we will explore the importance of communication and dialogue between antimonic market realms. How can responsible dissent pathways alter the valuation of dissent (and the communities within which it is voiced) and thereby disperse market power back to communities of resistance as a non-violent socially re-embedded process? The core interest of this case study is that when collective consciences clash, violence can be excised if access to pathways of responsible dissent (similar to information access) is built into the asymmetrical communities which comprise the markets of the global city.

Market corruption in free trade development paradigms (as in the third case study) reveals how the hegemonic globalisation of trade has co-opted law into the provision of exploitative market relationships. Essential for this analysis are reflections on how the North/South 
economic divide has and is producing neo-colonial fissures which, through the joint pressures of free trade market exploitation and patent/ trade mark information monopolisation, promote market deviance as a method for accessing limited property benefit. Organic cultures of obligation and dependency in the developing world have become mechanically corrupted as a consequence of the global push for shareholder profit as a driving motivation behind aid investment, and this is the process of disembedding through development regimes such as foreign direct investment. The double movement has been for the weak state, and sometimes coalitions of international and domestic organisations, to challenge law's part in failing to ensure a more equitable market frame, and its collusion in marketing the business imperatives of corruption under a distracting veil of morality and breach of public trust. Countermovements identify as grassroots communitarian resistance struggles which are demanding control over the determination of traded property, and even over state frames and functions which have authorised exploitation. These resistance movements are not analysed in ideological or political frames, but rather as actors networked together with diverse motives but with the shared purpose to wrest back market power and material access to property which has been disenfranchised through trade.

Our critical review of law's failings in facilitating the move to a new world order is not limited to some idealistic communitarian compatibility mode. That said we can see the practice of law being left in the wake of evolving property arrangements and non-law processes for their negotiation and transaction. Already non-legalist dispute resolution modes are filling the gaps in market confidence, of which overpriced and adversarial legal agency seems unaware, to remedy in its current commodified mode. The relationship between law and a broader communitarian consensus, if it was ever in place, is now in market economies so distant as to be aspirational. Thus where can law move in order to shape change for the majority rather than resist it for the benefit of the cashed-up few?

\section{LAW AS A CHANGE AGENT?}

How law becomes a willing party to change when it is notoriously reactionary in its regulatory function, is a practical challenge for the analysis to follow. A criticism of the Durkheimian approach to collective conscience formation and transition is the absence of specifics about what stimulates a mass move from one consciousness to another, particularly where such occurs quickly, spontaneously and in the face of 
other strong deterrent regulation. How did the downloading generation come to be? What is its new moral compass? How does it view the nature of property with which it is dealing? How is it understood by those responsible for attempting to regulate its behaviour? In the case of terrorism, how does resistance-made violence revert to responsible dissent, when the global city continues to offer up no more than blocked avenues to other forms of property benefit? In the discriminatory context of free trade, how do corrupt markets become the norm in a world of free trade and imprisoned knowledge?

Law as a contemporary control agent is operating within diverse community consensus: information exclusivity and universal access; labour exploitation and worker compliance; market corruption and obligation/dependency facilitation. But it is not enough to say that law's role is to constantly mollify competing market predispositions.

This practical dilemma (between what might be seen by some as pathological and some as normal) is avoided if what is desirable is declared to be what is healthy, and if the state of health is something definite, inherent in things, for at the same time the extent of our effort is given and defined. There is no longer need to pursue desperately an end which recedes as we move forward; we need only to work steadily and persistently to maintain the normal state, to re-establish it if it is disturbed, and to rediscover the conditions of normality if they happen to change. ${ }^{68}$

This invocation, if directed toward more equitable and socially sustainable property arrangements, will infuse law as a regulator with its own communally responsive normality that its normative precepts extol, and search out the practical relevance of its prevailing principles which protect general good rather than promote individualised wealth creation.

In moving to new levels of engagement with property via access ahead of possession and ownership, new law will no doubt come up against hegemonic state interests. Such negative intersections will challenge previously assumed symmetries between the law and the state as law returns to the social while the state (and what is euphemistically termed national interest) remain outside any role as the voice of the social.

\section{RADICALLY RETHINKING LAW AND PROPERTY}

The inextricable connection between law and property, particularly in common law traditions, is all about commodification. Wealth in the

68 Durkheim (1982), p. 104. 
feudal form was land and land was certified and alienated through law. In the shift to capitalist/mercantile economic frames, the enclosure of common land and the concurrent restrictions on access and use determined land value and the market in its transaction. Whether it is land, moveable property, financial instruments or futures, property claims its value through designating inclusion or exclusion from access and use and law acts as the commercial discriminator.

As noted already, all this is changing in the information age. The valuation of property is no longer essentially the product of inclusion/ exclusion barriers, legal or otherwise. The notion of 'real' property is essentially dependent on temporal and spatial location, as are the laws of states and territories which determine its market value. In the ephemeral internet context, access to knowledge is no longer critically dependent on law's capacity to include or exclude use. That law has chosen not to determine knowledge as property seems to have little effect on its contemporary market valuing, even when law attempts to create knowledge scarcity through contract relations, or IP registration. In fact, the value in knowledge through internet information is more likely to be enhanced through its wider dissemination. Even where this is not so simple, the capacity for law to exclude/include access to internet information has so diminished that the barriers are sufficiently porous, and the collective conscience concerning freedom of access is so firm, that the battle to value information as property through legal containment is lost.

If we consider the three contesting collective conscience case studies in terms of market empowerment, then this argument becomes clear. Internet downloading is the determinant of a generation. Law is being forced to accommodate this new and powerful consciousness. As for markets in the violent practice and control of dissent, disaffection with the war on terror and the state's incapacity to manage distorted perceptions of risk will shift the boundaries of fear and resistance. That said, as disempowered communities of resistance come to realise their nonviolent communitarian muscle in global cities otherwise ruled by ageing elites (authoritarian populism is a contemporary example), then the old regimes of market power, obligation and dependency will fall away, violence or not. The final case study reveals the corruption of markets when trade is reduced to neo-colonial relationships of greed and exploitation, plagued by the paradox of market freedom and information exclusion. Simply opening up the pathways to property will not overcome the potential for exploitative market arrangements accompanying that change. This is where the case for positive and responsible legal regulation becomes strongest, and presents a visualisation of law as a principled communitarian resource, ensuring that new forms of property, 
new fields of location and new pathways for access do not become captured by the same discriminatory interests which characterised law and property in the pre-information economy.

As the terrorist violence case study reiterates, society is a system of communications, some open and some constrained. Law is concerned with the structures and mechanisms through which communications develop. As law is a social fact at a particular time and space, law should reflect the diverse social perspectives which emerge from social sectors (spaces) enabling accessible communication pathways of engagement that communitarian theorising requires. ${ }^{69}$

Being a social fact, law provides the boundaries within which the collective conscience formulates and strains to break free. ${ }^{70}$ Strong and weaker formulations of the collective conscience represent different and often contesting social perspectives that influence, and are influenced by law which is in turn dependent on the tension emerging out of this interaction.

Our study is interested to identify new social forms and frames which count as law in diverse social perspectives. Our case studies question the nature of social relations that law should regulate. ${ }^{71}$ In our imagining law can transform into a market force which constructively subverts 72 exclusionist traditions and relationships. The new law which both stimulates and emerges through markets re-embedding is imbued with cultural and political relevance by reflecting communitarian needs as a social resource.

How will new law assist in the ordering of transitional markets (re-embedding and experiencing fundamental power dispersal)? Law must observe and establish contact with social systems as 'communicative centres of reflection' from which social values and interests generate. ${ }^{73}$ Exploring law in this social space is not only to interrogate values and interests as they are translated and constituted in social sub-systems (particularly the market, and market economies) but also to understand law as a communication technique deemed necessary as a limitation to

69 Teubner, G. (2007), 'The private/public dichotomy: After the critique?', Republic: Re-imagining Democracy, www.re-public.gr/en/?p=99.

70 Durkheim (1982).

71 Cotterrell (2013b), p. 133.

72 Erlich, E. (1936), Fundamental Principles of the Sociology of Law, Cambridge, MA: Harvard University Press and Erlich, E. (2002), Fundamental Principles of the Sociology of Law, New Brunswick: Transaction.

73 Teubner, G. (1993), Law as an Autopoietic System, Oxford: Blackwell, pp. 86-90. 
any system. ${ }^{74}$ Through limitation, law constrains excess, imbalance and incongruity. In this respect law recognises the constituting function of social realities, ambiguous and conflictual as these may be, and introduces fundamental values inherent to them. Through providing the normative backbone for the transformation of property and the re-embedding of markets, law will confirm its communal utility and its regulatory relevance as a social fact only when it gives principle some actual market presence.

Too often law has been burdened with the responsibility of removing economic or political injustice. This obligation has meant deciding between divergent external realities communicated from society. For instance, where is the pathway to reconciling market pricing policies and human rights access protections in intellectual property disputation? For instance, in litigation contesting the rights of patent-holders against the social benefits of unregistered generic derivatives, the courts often demonstrate a sensitivity to pre-eminent claims for social good. In sometimes preferring the interests of the disempowered in vulnerable market spaces over the exclusionist rights of IP beneficiaries, the law opens pathways and mechanisms for the acquisition of information, and thereby demonstrates law's capacity for stimulating power dispersal, reconstructing the universal and contained value of information and thereby allowing law to revalidate itself as a communitarian regulatory force.

Teubner argues that law is capable of producing new law in evolving the means of irritation, re-entry and reconstruction processes. Irritation (such as generic drug manufacture) is necessary, so the argument goes, to initiate the transformation of law. Irritation is usually produced through conflict which can arise out of shifts in the collective conscience (arguing for a freer access to medical benefits against the wealth that drug sales offer IP beneficiaries). In this respect, essentially communitarian social conflict presents for law an opportunity to incorporate external constituencies from legal argumentation (like if the general public is excluded from benefit through patent restrictions). When a social construct such as property has irritated the legal system, accompanied by a strong counterconsciousness demanding alternative meanings, then law is forced into a new phase of recognition, and judicial decision-making rather than legislative restrictions becomes the medium for change rather than for resisting it.

74 Black, J. (1996), 'Constituting self-regulation', Modern Law Review, 59 (1), 24-55, at 55 . 
Stepping back to how law is irritated into reconstruction, it is useful to consider how social sub-systems, that can provide the need for law to re-enter a social space with a reconstructed form, possess a constitutive function because they construct themselves according to their internal rationality. Extending the generic drug example, in a market setting this may mean commodity pricing, or even political power to differentiate market preferencing (recently evidenced in President Trump's populist attack on pharmaceutical over-pricing). In altering the collective consciousness, sub-systems such as economy and politics have limitative functions over law (recognised by judges more in tune with popular wisdom than legal literalism) and vice versa because they establish their own boundaries and thereby cognitively inhibit neighbouring sub-systems.

The normative closure of law means that it is only capable of reconstructing the social value and interests of other sub-systems through offering different meanings to their operations according to legal rationality. But legal rationality is not set in stone. Altering and growing the structure of that rationality makes possible the changing of meaning for the operation of other sub-system, even leading to the breaking down of entrenched divisions, system-to-system. A new approach from legal agency, such as interventionist judicial decision-making, allows for an already-institutionalised bridge between normative closure and cognitive openness across sub-systems.

In order to achieve its transformative potential, new law needs to stabilise the independent expectations of other sub-systems and their participants by reconstructing them within the context of an inclusive legal rationality. New law, reconstructed through the present possibilities of de-commodified legal agency, can enter other sub-systems such as the market and assist in changing the structure of meaning such as what is property. This critical lens would allow entrenched divisions between the included and the excluded to be overcome.

Once irritated and reconstructed, re-entry is a key phase through which law can internalise the dynamic rationalities developed in other subsystems and thereby transcend its own conventional boundaries by employing external cognitive forces to ensure its congruence with changing collective consciences. ${ }^{75}$ On the other hand, free of externally imposed limitations which are inconsistent with powerful contesting

75 Skordas, A. (2009), 'Is there justice in international law', in G. Calliess, A. Fisher-Lescano, D. Wielsch and P. Zumbansen (eds), Sociologische Jurisprudenz, Berlin: De Grychter Reicht, pp. 179-197. 
collective consciences, law can establish clear processes by which selection, variation, and retention of values and interests are made in an orderly rather than sectoral and sporadic fashion.

Considering how law can assist in the re-embedding of markets, the interrelation of law with other sub-systems, advocating an inclusive agenda, allows for the co-evolution of sub-systems such as the economic and the social, in which law can recreate a communally sensitive and responsive image of the economy and the social, and vice versa. In this way law moves from its current bind as a reactive market force, to an agent of change in ordering changing markets. And it can do so by exercising dynamics of legal institutions and processes currently available within its sub-system, such as litigation within the courts.

New law involves a normative framework offering freer points of access (that in our example would be subsidised professional representation before the courts for class actions and public interest). Thereby it communicates with other social realities in ways which both assist in their reconstitution and determine limitations over that process in a strong normative constitutional form. Based on a firm commitment to knowledge dissemination, law's normative frame provides boundaries to the collective conscience in terms such as social-embeddedness, ordering, equality, and justice as responsible forms of power sharing, rather than replacing old exclusionist interests with anarchy.

New law will represent a dynamic communication pathway for expressing governed social good. It provides a capacity for exposing binaries such as legal/illegal, and breaking these down due to its mechanism for transacting meaning and thereby determining legitimacy. In the sub-system of a market, new law questions the law it replaces by revealing opposing market permissions entrenched in exclusive access to property based on price. One such permission is the ultimate power of the consumer in community, and the consumer community as a political and economic imperative influencing the transaction of law.

Law as a device for commodifying property value in terms of exclusionist market pricing, discriminates market power and magnifies individualist wealth creation through initiating and maintaining property arrangements which depend on enforcement rather than trust and consensus. New law, on the other hand, permits market positioning based on more just configurations of power. In this way new law acts as a driver and not a distinguisher of market freedom. New law is in turn driven by its own normative constitution which reflects the perennial principles of justice and fairness. That normative constitution is returned to its purpose 
in promoting fluid social good, and thereby acting as a community resource while constraining community confusion. ${ }^{76}$

While new law is reconstructed from conventional legal technologies, it runs parallel to other law frames, permitting critical reflection on their normative masking functions. In its points of re-entry (such as more equitable access to adversarial litigation) new law can expose the old spaces which law occupied, advancing state interests and the dysfunctional applications of normative codes in otherwise discriminatory market economies.

New law impacts on other legal sub-systems which operate within fictitious paradigms such as property rights ${ }^{77}$ and treasure and extol mechanical rather than organic concepts of access, possession and ownership. The paradox of new law/old law is a story of facilitative wrongs rather than of illusory and masking expressive rights (wrongs in terms of 'property as theft', see Chapter 2). Pre-existing legal frames have employed the influence of similar normative constitutions to that of new law, to defeat social good. Law in such settings is an irritant favouring opportunities within other social realities (such as markets for property) to diminish the core values of normative constitution and instead perpetuate exclusion in the name of equality, and disembed market participation from society in the name of conscionability.

\section{'SEEKING SIMILARITY, APPRECIATING DIFFERENCE'78}

When law is seen as communication spaces and processes, the communities in which new law will emerge as a resource are ultimately networks of trust. What remains of this chapter does not permit us to satisfactorily interrogate how a collective conscience can bind as a result of disparate networks coming together with dissimilar motivations but somewhat common objectives. Actor-network theory offers a useful entry

\footnotetext{
76 Perry-Kessaris, A. (2011).

77 Fictitious we argue, because rather than conferring benefit as an inherent or universal value of some fundamental prerogative, which we challenge alienable property as claiming, they are little more than mechanisms for enforcing commodity valuing.

78 Cotterrell, R. (2002), 'Seeking similarity, appreciating difference: Comparative law and communities', in A. Harding and E. Orucu (eds), Community as a Legal Concept: Comparative Law in the 21st Century, London: Kluwer Law International, pp. 35-54.
} 
into understanding complex networking within contested consciousness. Actor-network theory applies when specific networking materials (or bonding agents) can be identified as important influences over social connection. ${ }^{79}$ If as we have presented, a collective conscience is a complex and fluid set of heterogeneous sub-networks with different broader agendas, then material access and advancement through property possession, such as internet information, can be identified as playing an essential role in governing how actors deploy networking effects and powers in manners similar to the way in which human intercourse is otherwise organically structured. In this way we can talk of the exchange of digital information creating internet communities.

Law is a regulatory externality moderating networking materials, in the form of property, which should bond a network, and in structuring markets in materials which network. In essence, law's role in the embedding, disembedding, re-embedding triple movement is governed by the presence or absence of interpersonal trust. To the extent that economic action and interaction are influenced by trust and its deficit (see in particular, the prevalence of performed contractual obligations), then such action is always somehow, and to some extent embedded, from the fleeting to the stable. When law promotes individualist benefit over communal resourcing, network bonding based on trust (rather than enforcement) will be the casualty.

This chapter has touched on the forces which tend to remove law from social good, particularly in its perpetuation of commodified property relations. One way of seeing the reasoning behind this is the overemphasis on law's economic dimension, and its concurrent inability to support non-economic relations in society because they do not involve cash profit. In this setting, law as it is commodified becomes priced on service/agency scarcity, losing along the way its sense of a more sustainable social purpose and utility. Within market economies, law as a force for social good becomes disembedded, and understanding how this happens when property is being reconfigured as a social fact, enables our later projections on where law needs to head if it is to assist property in its transformation toward social wealth beyond economy.

A critical Polanyian perspective has thus, first, to de-construct the Hayekian way of embedding even the law (and its inherent normativity) in economic

79 Latour, B. (2005), Reassembling the Social: An Introduction to ActorNetwork-Theory, Oxford: Oxford University Press. 
rationales, and, secondly, to reconstruct law as a social institution which also reflects the rationales and values of other social spheres. ${ }^{80}$

The difficulty we face in seeing law as part of the problem as well as the possible solution for property's disenfranchisement outside social good, rests in the way that law can simultaneously compound and expose the discourse of commodification which is at the heart of disembedding dynamics. The answer to this difficulty is to envisage new law and original property embraced in a somewhat unpredictable dynamic stimulated by seismic shifts in contested collective consciences.

Economists pretend that the economy is an autonomous 'self-regulating' set of relationships. Lawyers collaborate by dressing humans and nature as 'fictitious commodities', Labour and Land, and present them as having been produced for the sole purpose of being sold. But off-stage lurks reality in which the action and reaction remain embedded in society and society always 'protect(s) itself against the perils inherent in a self-regulating market system' 81 ... (law's capacity to act as a communal as opposed to a commodified resource) expressed the acceptable extensions of markets in respect of genuine commodities within economic networks of community; and maintained spaces for the co-ordination of inter-network values and interests in which the counter-moving restricting, checking, and resisting of markets duly took place. ${ }^{82}$

Law as a communal resource is what we need to explore as the analysis unfolds. The internet is a frame for communication between communities at the level of what Perry-Kessaris identifies as the instrumental, economic, traditional, effective and belief-based. Cotterrell pitches against this, law's aspiration towards something more than '... the society of morally unconnected, rights-possessing individuals that liberal philosophy tends to presuppose' ${ }^{83}$ And the communitarian counter-vision for law does not presuppose some mechanical consensus. As our later discussions - within the case studies of terror and trade - of Luhmann's

80 Frerichs, S. (2011), 'Re-embedding neo-liberal constitutionalism: A Polanyian case for the economic sociology of law', in C. Joerges and J. Falke, Karl Polanyi: Globalisation and the Potential of Law in Transnational Markets, Oxford: Hart Publishing, pp. 65-84 at p. 81.

81 Polanyi, K. (2001), The Great Transformation: The Political and Economic Origins of Our Time, Boston: Beacon Press, p. 80.

82 Perry-Kessaris (2011), p. 411.

83 Cotterrell, R. (2006), 'Community as a legal concept? Some uses of a law-and-community approach in legal theory', in R. Cotterrell, Law, Culture and Society: Legal Ideas in the Mirror of Social Theory, Aldershot: Ashgate, p. 18. 
ideas of dissent and asymmetry (in healthy, functional communities) explores (and see Chapter 6), community does not imply an absence of conflict. There will always be in dynamic societies, some contested collective conscience. Law's role in the facilitation and evolution of contestation is to create gateways and maintain pathways where participation in responsible contestation can occur.

It is primarily in law's capacity to act as a communal resource that the hope of those who would counter-move resides. The values and interests that underpin actions and inter-actions (individualistic or communal) in one type of social action or interactions (instrumental, affective, belief or traditional) may be in direct conflict with the values and interests underpinning other actions and interactions. Such conflicts are the beating heart and meaningful soul of embeddedness, and they can be made more productive, or less destructive, when law acts as a communal resource. ${ }^{84}$

We endorse Perry-Kessaris' observation that a community lens highlights the distinction between two of law's many faces, both of which are starkly revealed in the struggle over the internet information economy:

- one which is directed towards supporting the ad hoc actions and interactions of wealth-seeking individuals;

- the other determined to support those relatively stable and trusting interactions on which social bonds rest and community networks rely.

As far as property arrangements and law's conventional involvement are concerned, it is easy to see law as only interested in the protection and promotion of individualised rights and interests. Such an analytical cul-de-sac is distinctly ahistorical and takes as a given notions of property which are alienated, class-dependent, and exclusively commodified. The arguments to follow are in no way so hidebound. To confine the face of law to such an individualist, economic and market-oriented profile would deny what we argue for as its exciting transformative potential. The challenge lies for those who would gaze on another face of law - one which is engaged, networked and interested in social good - to enunciate law as a communal resource.

Difficulties are presented in an argument favouring law as a communal resource when the strong counter-narrative of intellectual property is in its death throes. As the Washington consensus advocacy of small state

84 Perry-Kessaris (2011), p. 410. 
and deregulation relied for its force on the straw man that less regulation ipso facto meant more market freedom, so too the champions of intellectual property rights encase the debate about law's role in the information economy only in terms of individualist economic rights and their priority. Such economic discourse is incapable of accommodating non-economic values and interests; an analytical myopia which almost saw the discipline relegated to irrelevance in failing to explain or predict when it is the failure of the market (rather than market failure) which is at issue.

At best (economics relegates other interests) to a non-speaking cameo role; at worst, it writes them out of the story entirely. One problem is that money has long been the go-to numeraire - measure of value - for economists, because of a genuine confidence that everything of value has a price and money is the most efficient signal of those prices ... In the language of community, the 'fragmentary' judgement of economics is worrying because it is an economic (type) and an individualistic (form) story in which the speaking roles are given to those engaged in economic interactions, and the script is composed entirely of monologues. So it blinds us to the reality that all actors are engaged in multiple, diverse and complex patterns of social action and interaction. ${ }^{85}$

Law as a communal resource needs, for the purposes of our analysis, first to be repositioned outside the discourse of individualist, commodified property rights. It is unlikely that even at the level of discourse alone, this will be anything but a painful transformation (see Chapter 2). Rather, as is currently the case, law as a commodity operating the province of intellectual property protection, will tensely coexist with law as a communal resource to open up the social good in information economies. As we argue (in Chapter 6) by adopting Proudhon's approach to the impossibility of property, and Pashukanis' conviction concerning the withering away of bourgeois law, ${ }^{86}$ the communal resource reading of law must grow to dominate understandings of law's regulatory utility and as such will replace law as an exclusionist market commodity, marketing exclusionist property arrangements. Charting this transformation will require a belief in law's normative resilience, and confidence that the

\footnotetext{
85 Perry-Kessaris (2011), pp. 406-407.

86 Pashukanis, E. (1980), 'The general theory of law and Marxism', in P. Beirne and R. Sharlet (eds), Pashukanis: Selected Writings on Marxism and Law, London and New York: Academic Press.
} 
alternative collective conscience will not be so disenchanted with law as the pimp of property as to withhold trust in its transformative, communal potential. 